UDC 667.662 .1

T. N. GZOGYAN, Head of laboratory, mehanobr1@yandex.ru

S. R. GZOGYAN, Senior Researcher

E. V. GRISHKINA, Junior Researcher

Belgorod State University, Belgorod, Russia

\title{
RICH IRON ORE IN THE BELGOROD REGION OF THE KURSK MAGNETIC ANOMALY AS POTENTIAL RESOURCE FOR METALLIZATION
}

\begin{abstract}
Introduction
The Belgorod iron province in the Kursk Magnetic Anomaly is the world's largest holder and a very promising supplier of rich iron ore. By the contents of useful mineral, slag-forming oxides and harmful impurities, this large and unique iron ore province is a potential source of high-quality versatile stock for metallurgy, including coke-unfueled metallurgy [1-3]. Advantageous economic location, mature infrastructure, human resources, unlimited potential of rich iron ore and other minerals (bauxite, garnet, etc.) for mining and processing makes the Kursk Magnetic Anomaly deposits attractive for investment [1-5].

Production of high-quality iron ore is on the front burner today for the demand for low-grade iron products has dropped. Russia lacks the experience of such production from natural rich ore while industrial processing of such ore is
\end{abstract} widely developed in the world (Australia,

Brazil). In this regard, rich ore is a source of feed stock for metallized product of special purpose.

By now, such deposits as Visla, Gostishchevo, Shemraevka, Yakovlevo, Bolshetroitskoe, Melikhovo-Shebekino, Olempiyskoe, Olkhovatka and Razumenskoe have been explored and appraised. The discovered natural rich mineralizations include complex iron-bauxite ore [1-5].

The rich ore deposits are composed of uniform geological mineralogical types, which, depending on the content and proportion of ore-forming minerals and secondary superposed processes, mainly are: martite and iron-micamartite, martite-hematite and martite-hydrohematite and goethite, carbonatized and re-deposited ore [4-7]. Chemical composition of basic rich ore types from the promising deposits points at their high metallurgical value (Table 1). Spectral analysis reveals calcium, magnesium and scarce dispersed elements (nickel, vanadium, tin, molybdenum, zinc, lead and copper). Of the greatest interests is germanium ranging from 2 to $42 \mathrm{~g} / \mathrm{t}$ of mass fraction averaged as $9.1 \mathrm{~g} / \mathrm{t}$.

Rich ore of residuum (Belgorod regional type) contain four different geological types of commercial value distinguished quantity, material composition, mining method and processing technology, physical, mechanical and metallurgical properties, namely, stoilensky, chernyanka, shemraevka and yakovlevo. The dominant role belongs to the yakovlevo and shemraevka types of ore.

The yakovlevo type is high-grade iron-mica-martite and martite ore of low strength.

The pioneer in terms of exploration and study in the region is the Yakovlevo deposit. With regard to identified resources and quality of ore, the deposit ranks second to none equally in Russia and in the world. This is one of the largest deposits (overall category $B+C_{1}+C_{2}$ reserves total $6 \mathrm{Bt})[1,5]$. Iron mass fraction varies from 61.0 to $65.0 \%$ per sites, and its maximum is $69.7 \%$; the ore contains little slag-forming oxides and trace amount of harmful impurities. Yakovlevo Mining and Processing Plant extracts and processes iron ore with production of agglomerates at a commercial scale. The composition and properties of ore enable production of metallization stock by means of deep concentration.

The shemraevka type is loose martite ore with iron mass fraction from 64.0 to $69.0 \%$, which occur in association or 
Table 1. Chemical composition of basic rich iron ore types per deposits in the Kursk Magnetic Anomaly

\begin{tabular}{|c|c|c|c|c|c|c|c|c|}
\hline \multirow[b]{3}{*}{$\begin{array}{l}\text { Components } \\
\text { and oxides }\end{array}$} & \multicolumn{8}{|c|}{ Mass fraction of components and oxides in mineralogical variety per deposits, $\%$} \\
\hline & \multicolumn{2}{|r|}{ Visla } & \multicolumn{2}{|c|}{ Gostishchevo } & \multicolumn{2}{|c|}{ Shemraevka } & \multicolumn{2}{|c|}{ Yakovlevo } \\
\hline & $\begin{array}{c}\text { Martite } \\
\text { and iron } \\
\text { mica- } \\
\text { martite }\end{array}$ & $\begin{array}{l}\text { Hydrohematite- } \\
\text { martite and } \\
\text { martite- } \\
\text { hydrohematite } \\
\text { with goethite }\end{array}$ & $\begin{array}{c}\text { Martite } \\
\text { and iron } \\
\text { mica- } \\
\text { martite }\end{array}$ & $\begin{array}{l}\text { Hydrohematite- } \\
\text { martite and } \\
\text { martite- } \\
\text { hydrohematite } \\
\text { with goethite }\end{array}$ & $\begin{array}{c}\text { Martite } \\
\text { and iron } \\
\text { mica- } \\
\text { martite }\end{array}$ & $\begin{array}{l}\text { Hydrohematite- } \\
\text { martite and } \\
\text { martite- } \\
\text { hydrohematite } \\
\text { with goethite }\end{array}$ & $\begin{array}{c}\text { Martite } \\
\text { and iron } \\
\text { mica- } \\
\text { martite }\end{array}$ & $\begin{array}{l}\text { Hydrohematite- } \\
\text { martite and } \\
\text { martite- } \\
\text { hydrohematite } \\
\text { with goethite }\end{array}$ \\
\hline $\mathrm{Fe}_{\text {tot }}$ & 64.12 & 59.56 & 64.47 & 54.51 & 65.11 & 59.39 & 63.19 & 59.4 \\
\hline $\mathrm{SiO}_{2 \text { tot }}$ & 3.0 & 4.86 & 2.68 & 5.42 & 2.54 & 4.89 & 4.35 & 5.66 \\
\hline $\mathrm{Al}_{2} \mathrm{O}_{3}$ & 1.42 & 2.39 & 1.93 & 6.19 & 0.98 & 2.94 & 1.25 & 3.94 \\
\hline $\mathrm{S}_{\mathrm{tot}}$ & 0.06 & 0.09 & 0.032 & 0.064 & 0.04 & 0.11 & 0.11 & 0.031 \\
\hline $\mathrm{P}$ & 0.08 & 0.09 & 0.08 & 0.17 & 0.09 & 0.11 & 0.014 & 0.05 \\
\hline $\mathrm{LC}^{\star}$ & 3.4 & 6.1 & 2.81 & 8.57 & 2.21 & 6.54 & 3.04 & 4.62 \\
\hline
\end{tabular}

inside large yakovlevo type ore bodies. The Shemraevka deposit ore is suitable for in situ hydraulic mining (total output of this method is 70000 tons of ore with the iron mass fraction of $66.5-68.5 \%$ ).

The basic metallic minerals are martite and hematite (iron mica), carbonates (siderite, calcite), magnetite (rare), with considerable hydrohematite, goethite and hydrogoethite. Some ore types contain considerable tributary marshalitized quarts and chamosite-kind chlorite. Some times, metamorphogene quartz, lepidocrocite, pyrite, marcasite, boehmite and gibbsite are observed as impurities, as well as single grains of chalcopyrite and galena.

Formation of epigenetic minerals in rich ore proceeded successively from chamosite (supergene chlorite) to siderite and ended with pyrite, which was governed by gradual buildup of reductive conditions. Chamotization at the top of the ore body was suppressed by more intense sideritization, and the zone of epigenesist parted in the section as a result (sideritization is maximal in the subsurface layers of the ore bodies, while chamotization is the largest on the lower horizons). The parting is most pronounced in the Yakovlevo deposit and other areas of the region due to the larger general thickness of rich ore of residuum (to $430 \mathrm{~m}$ ); chamotization zone hear reached 120 in thickness [6-9].

The mineral variety is conditioned by different mineral compositions of bedrock and by secondary processes (carbonization, chloritization). The dominant intensity process in the majority of deposits is sideritization that governs physical and mechanical nonunformity of ore bodies, as well as variability of mineral and chemical compositions of ore, both depthward and along the strike.

The first-stage epigenetic minerals (siderite, chamosite and pyrite) are metasomatic formations [4, 6-9]. The minerals form a fine-grain cementing mass in ore, with all observable stages of martite replacement (up to complete) by siderite. The chemical analysis of monomineral fractions shows assonance with theoretical composition of siderite ( $\mathrm{FeO}-62.1$ ( $\left.\left.\mathrm{Fe}_{\text {tot }}-48.3\right) \%, \mathrm{CO}_{2}-37.9 \%\right)$. In connection with this, mass fraction of total iron drops in sideritized rich ore.

\section{Mineral composition of natural rich ore in the Kursk Magnetic Anomaly}

Tests of more than 300 technological samples taken from natural rich ore of the Yakovlevo deposit during detailed exploration show the representative textural, structural and mineralogical characteristics of this ore. The composition and properties of the samples were revealed using a system approach-grain size distribution and chemical analysis, Mossbauer spectroscopy, X-ray phase analysis, electron and optical microscopy, high-temperature magnetometry and microprobe analysis. During the tests, the samples were subjected to ultrasonication, and the fineness of the distinguished fractions was checked in the Mossbauer effect study, as well as the X-ray phase, chemical and mineralogical analyses [10-12].

The Mossbauer spectra were obtained using spectrometer Ms-1104 Em (Rostov State University, Rostov-onDon) ad the spectra processing program Univem Ms. The Mossbauer source was Co 57, the matrix was Rh, and the isomer shift was determined relative to a-Fe.

The size control was implemented using the laser diffraction-type analyzer Analysette 22 NanoTec (Germany) by the Fraunhofer technique (measurement range from 0.1 to $1021.87 \mu \mathrm{m}$, resolution was 102 channels $(20 / 383 \mathrm{~mm})$; absorption was $11 \%$, duration made 90 scans) and the analytical screening machine Minor (Endecofts Ltd, England).

The tests determined magnetic and strength characteristics of the samples.

Formation of the Yakovlevo ore proceeded concurrently with subtraction of alkaline and alkaline-earth elements, accumulation of iron oxides and alumina as well as secondary carbonatization and chloritization processes. As with the other ore fields in the region, the Yakovlevo deposit contains several mineralogical types: loose and half-loose iron-mica-martite, martite-hydrohematite, hydrogoethite-hydrohematite; siderite-iron-mica-martite; martiteiron mica chloritized re-deposited ore.

The most mature bedrock is iron mica underlying rich iron mica-martite ore (blue iron ore). Less adult silicatemagnetite ore underlays rich martite-hydrohematite and hydrogoethite (red iron ore). Adjoining definite type metamorphic rocks, the rich ore inherits their texture. Percentage of loose and half-loose ore ranges from 36 to 60 per deposits and is from 53.7 to 63.7 in the Yakovlevo field. Iron mica-martite ore is represented hard, half-hard, loose and half-loose varieties depending on the degree of chlorite cementation. Martite-hydrohematite and hydrogoethite ore is only loose and half-loose, while carbonitized ore is only hard and half-hard kinds. 
Coefficient of magnetization varies from 39.85 to $65.010^{-6} \mathrm{~cm}^{3} / \mathrm{g}$ in loose and halfloose iron mica-martite ore and from 32.13 to $65.3 \cdot 10^{-6} \mathrm{~cm}^{3} / \mathrm{g}$ in hard and half-hard ore; the main different is the mass fraction of total iron, iron oxide and crystallization water.

By the compressive strength value, the ore is grouped in 5 categories (Table 2).

Martite, iron mica and iron mica-martite (blue) ore of the characteristic blue color has the highest mass fractions of total iron (66.24-68.26\%) and iron oxide (91.48-93.7\%) while the mass fraction of crystallization water is low $(0.41-1.2 \%)$. The ore has a pronounced texture. These ore varieties occur together in Table 2. Quality of basic rich îron ore types

\begin{tabular}{|c|c|c|c|c|c|c|c|}
\hline \multirow{2}{*}{ Type of ore } & \multirow{2}{*}{$\begin{array}{l}\text { Category } \\
\text { of strength }\end{array}$} & \multirow{2}{*}{$\begin{array}{c}\text { Ultimate } \\
\text { compression } \\
\text { strength, } \mathrm{MPa}\end{array}$} & \multicolumn{5}{|c|}{ Mass fraction, $\%$} \\
\hline & & & $\mathrm{Fe}_{\text {tot }}$ & S & $\mathrm{SiO}_{2}$ & $\mathrm{Al}_{2} \mathrm{O}_{3}$ & $\mathrm{P}$ \\
\hline \multirow{5}{*}{$\begin{array}{l}\text { Iron mica- } \\
\text { martite }\end{array}$} & Very hard & $>58.84$ & \multirow{3}{*}{$57.0-59$} & \multirow{3}{*}{0.15} & \multirow{3}{*}{$5.5-10$} & \multirow{3}{*}{1.9} & \multirow{3}{*}{0.03} \\
\hline & Hard & $\begin{array}{c}29.42- \\
58.84\end{array}$ & & & & & \\
\hline & Half-hard & $9.81-29.42$ & & & & & \\
\hline & Half-loose & $1.96-9.81$ & \multirow{2}{*}{$66-68.5$} & \multirow{2}{*}{0.05} & \multirow{2}{*}{$0.8-2.5$} & \multirow{2}{*}{0.75} & \multirow{2}{*}{0.09} \\
\hline & Loose & 1.96 & & & & & \\
\hline \multirow{2}{*}{$\begin{array}{c}\text { Martite- } \\
\text { hydrohematite }\end{array}$} & Half-loose & $1.96-9.81$ & \multirow{2}{*}{$59-61$} & \multirow{2}{*}{0.07} & \multirow{2}{*}{$4-5.5$} & \multirow{2}{*}{2.3} & \multirow{2}{*}{0.04} \\
\hline & Loose & 1.96 & & & & & \\
\hline $\begin{array}{l}\text { Hydrohematite } \\
\text { hydrogoethite } \\
\text { (red) }\end{array}$ & $\begin{array}{l}\text { Clayey, } \\
\text { plastic }\end{array}$ & - & $55-58$ & - & $5-7$ & 4.2 & - \\
\hline
\end{tabular}
the deposit and are integrated into one mineralogical type making 30 to $60 \%$ of overall reserves.

Martite ore occurs sporadically in the form of the thickest beds with finely banded texture governed by alteration of loose (2-6 mm) and dense (1-2 mm) interbeds. Hematite (iron mica) is structurally and texturally interlinked with martite. Hematite in the form of coloform zones and fine irregular, pseudo-flakes (2-6 mm long) and laths fills voids in martite aggregates. Some flakes or complex eyelets often form monomineral interbeds (to $1 \mathrm{~mm}$ wide) with uneven jaggy interfaces. The curves of differential-scanning calorimetry and thermogravimetry show the presence of hematite $\mathrm{a}-\mathrm{Fe}_{2} \mathrm{O}_{3}$ with the Curie point $675.8^{\circ} \mathrm{C}$, the higher temperature phase $\left(\theta=775^{\circ} \mathrm{C}\right)$, and effect of martite with $\theta=578^{\circ} \mathrm{C}$ in all monomineral fractions.

Martite ore contains inherent polyhedral aggregates of automorphic martite grains $(0.01-0.05 \mathrm{~mm})$ arranged in interbeds to $3 \mathrm{~mm}$ thick. Martite is pseudomorphic hematite after magnetite in the form of rhomb-dodecahedron or octahedron crystals. Magnetite is represented by two generations (relict and supergene), strongly susceptible to martitization, and rarely forms pseudomorphosis after hematite (musketovite). Martite is grey or grey-blue in color, some grains often enclose white-pink (reflected light) magnetite relicts (Fig. 1C). Magnetite builds up on wide planes of flakes and laths of hematite, and replaces martite by specific forms. The mass fraction of iron in magnetite ranges between 69.16 and $72.2 \%$, and averages at $70.61 \%$.

Supergenic magnetite occurs as regeneration skirting of martite grains and only in ore that has experienced secondary processes (carbonatization, chloritization).

Iron mica ore has lepidoblastic texture with hematite in thin interbeds $(1-2 \mathrm{~mm})$.

The mass fraction of iron in martite is $67.6-69.7 \%$ with average of $69.0 \%$ in hematite, $66.6-69.8 \%$ with average of $68.12 \%$ in hematite, and $66.4-67.7 \%$ with average of $66.9 \%$ in finely dispersed elements.

Three generations of hematite (Fig. 1a and 1b) include:

- crystalline generation of pseudomorphosis due to replacement of primary martite with preservation of its form;

- xenomorphic generation or aggregates of xenomorphic and crystalline generations formed as pseudomorphosa due to replacement of martite (magnetite);

- acicular generation formed in dissolution and redeposition of iron-bearing minerals, high-temperature hydrothermal activity product.
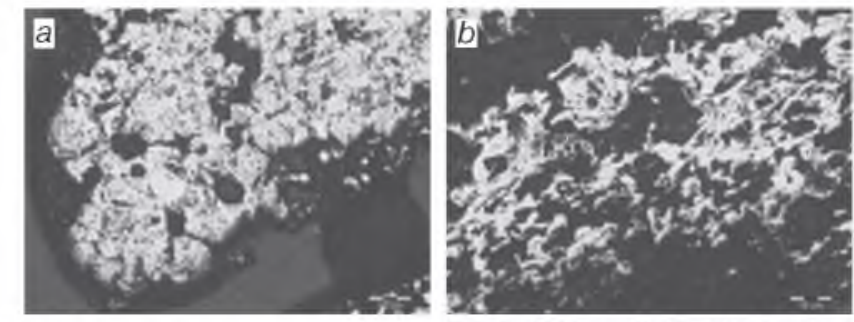

Fig. 1. Crystalline (a) and acicular $(b)$ hematite in chlorite and ferrous carbonate; martite in relic magnetite (c). Reflected light, magnification $\times 500$.

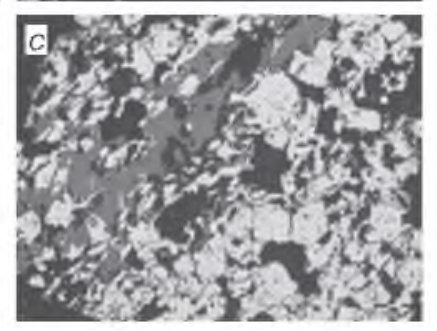

Size distribution studies classify blue-type rich ore as siltstone with typically high (40-80\%) mass fraction of coarse ( $d>0.05 \mathrm{~mm}$ ) silty material and insignificant (to $6.5 \%$ ) of submicron $(\mathrm{d}<0.002 \mathrm{~mm}$ ) particles.

Martite-hydrohematite (hydrohematite-martite) (blue-red) ore feature wine-red, tile-red, reddish and violet brown coloration, as well as cherry-cast dark-red, foxy and, seldom, strong reddish orange color when in powder condition. Furthermore, there are red (burgundy), russet (brown) and red-brown iron hydroxides composed of colloform columnar or earthy aggregates. This ore has eyelet-fibrous, porphyroblastic structure, nonuniform lamination with intercalation (1-2 mm thick) of martite and hematite, as well as with variation in color of the layers. Martite layers (to $60 \%$ of total mass) are compact, with characteristic metallic luster, and red or red-brown in color owing to nests and skits of iron hydroxide forming corrosive structure. In places, martite layers contain numerous pockets of chlorite.

The $\mathrm{X}$-ray diffraction analysis finds that the main oreforming minerals in this type ore are martite, hydrohematite and finely dispersed hematite; impurities contain hydrogoethite, chlorite, quartz, clayey material and, seldom, bauxite minerals. Chamosite-type chlorite is observed in the form of spots, nests and solid amorphous or cryptocrystalline layered concentrations. Chlorite fills voids between ore grains and aggregates as cement (Fig. 1b). 
Hydrohematite is a secondary ore-forming mineral, although in places it forms layers and dominates hematite and goethite. Hydrohematite is represented by a loose dispersion variety, colors layers tile-red, is observed in all varieties and is one of the main minerals in hydrohematite-martite ore.

Three revealed generations of hydrohematite are:

- the generation in quartz leaching voids: it has an exclusive value in red and hematitered oregenesis;

- the generation of chlorite, probably, in the presence of sufficient oxygen; may adjoin native chlorite slate;

- the generation of counter-veins (in cracks) in the form of healing joints with fine streaks (to $1 \mathrm{~cm}$ ); is often observed on parting planes of shale and particularly hematite interlayers with relic schistic structure in the form of shapeless spots or veinlets.

Martite-hydrohematite ore has lower mass fractions of total iron (53.33-62.25\%) and iron oxide (70.56-83.34\%) as well as increased mass fraction of crystalline water $(4.83-13.0 \%)$. Iron oxide is mainly associated with martite and hematite, and seldom with iron hydroxide, which is proved by the Mossbauer spectroscopy. Iron oxide is contained in chlorite, siderite, residual magnetite and pyrite. The mass fraction of $\mathrm{SiO}_{2}$ varies from 0.97 to $9.54 \%$ and is associated with relic and vein quartz, chlorite as well as, to a lesser degree, with hydromica and kaolinite. The mass fraction of $\mathrm{Al}_{2} \mathrm{O}_{3}$ ranges from 0.55 to $2.74 \%$ and is interlinked with chlorite and, slightly, with hydromica, kaolinite, gibbsite and boehnite. The mass fraction of $\mathrm{CaO}$ fluctuates as $0.19-1.5 \%$ and is associated with the calcite presence. The increased mass fraction of crystalline water $(4.83-13.0 \%)$ is governed by the higher mass fraction of hydrohematite, goethite and hydrogoethite.

Hydrogoethite-hydrohematite (red) ore is interlinked with martite-hydrohematite ore by means of stable thickness interbeds and makes up to $7 \%$ of total reserves in the deposit. The ore is clay-like and plastic when wet and stony and earthy-powdered when dry. In this connection, it is recommended to extract this type selectively and to process it separately given a dedicated technology is developed. The ore features very nonuniform spotty-laminated structure, from fine $(1-2 \mathrm{~mm})$ to coarse $(3-5 \mathrm{~cm})$, due to intercalation different in color and mineral composition. Layer-bylayer spotty coloration is dun, red-brown, ochroid-yellow and grey brown. The ore is mostly composed of earthy dispersion hematite and powdery iron hydroxides (hydrohematite and hydrogoethite) up to $80 \%$ by mass fraction. Dispersed hematite, hydrohematite, goethite and hydrogoethite form alternating irregular-shape zones zones and different-thickness interlayers. Local irregular nodules and grey clots are composed dense large-crystalline hematitedehydration product of iron hydroxides. There are occasional martite interbeds (to $5 \mathrm{~cm}$ thick), a well as irregular shape spots, veinlets and droplets of martite (to $25 \%$ ). This type ore also contains chlorite and clayey substance (to $3 \%$ ) in the form of the finest streaks and droplets, quartz (to $2 \%$ ) in the form of relic grains, and carbonate as thin leather coats. Hydrogoethite and goethite are observed as loose, earthy, brown material, which is clayey dark-brown in places, and are mostly products of decomposition of iron-bearing amphiboles and carbonates. Pure hydrogoethite is extremely rarely observed and has transverse-fiber structure. Goethite gradually transform to hydrogoethite and other iron hydroxides, which is show in coupled diagnostic characters. The mass fraction of total iron is 59.09 to $63.83 \%$, and the ass fraction of $\mathrm{SiO}_{2}$ varies from 2.4 to $2.63 \%[5,6]$. Hydrogoethite-hydrohematite belongs to the low grade with reduced mass fraction of iron, is unprocessed and is of low value for metallurgy.

Carbonate and carbonatized ore has massivebanded, coarse- to fine-grained structure, is dense, hard, of brown-grey and yellow-brown color. This type ore is a result of carbonatization of all ore varieties, although iron mica-martite and martite ore feature more intense and complete carbonatization. Hydrogoethite-hydrohematite ore exhibits much less and uneven carbonatization due to weak permeability. Carbonates are mostly represented by siderite (to $70 \%$ of ore mass) and calcite (tributary mineral) and less by sideroplesite and dolomite. Siderite is often one of the main ore-forming minerals and generates crystalline-grainy interlayers of variable thickness (to $30 \mathrm{~cm}$ ). Siderite represents interstitial tissue and cementation between 
martite-hematite aggregates, fills voids and cavities, and forms veinlets and nest of any shape and size.

The carbonatization zone accommodates supergene magnetite, as well pyrite and marcasite in frequent nests and concretions. Limonitization of siderite and its replacement by iron hydroxides is more often than not.

Chloritized ore is a result of intense chloritization of iron mica-martite and martite ore, where this process is weak in hydrogoethite-hydrohematite ore. Chlorite is represented by two generations:

- residual mineral after supergene alterations of sllicate parent rock minerals (amphiboles, biotite) with inherited lamination in layers (to $2 \mathrm{~mm}$ thick) or encapsulation of martite grains; occurs as flake-lath and felted aggregates of sage-green color, loose but denser in layers, and is weak cement;

- chamosite in spots of aphanitic texture, from green to black in color; is a strong cement, which makes ore stony, rock and half-rock. Chamosite is often associated with siderite and forms compound chamosite-siderite cement, or sometimes siderite metasomatically replaces chlorite. Intersecting veinlets and nests of calcite are seldom observed. Traced as whitish point nodules in placers, kaolinite is associated with boehmite. The chemical analysis of revealed monomineral fractions of chamosite from different deposits proves is variability event within the same ore field (Table 3). On the other hand, the microprobe analysis yields that the chemical composition of shemraveka-type chamosite varies in a narrow range $\left(\mathrm{Fe}_{\text {tot }}=39.2 \div 42.0 \% ; \mathrm{SiO}_{2}=21.0 \div 25.0 \% ; \mathrm{MgO}=0.8 \div 3.5 \%\right.$; $\mathrm{Al}_{2} \mathrm{O}_{3}=18.8 \div 25.7 \%$ ). Chamosite in the deposit under discussion is clayey, and amount of slag-forming oxides depends on the content of chamosite in ore.

Based on the geological and technological mapping of the Yakovlevo deposit, the technological classification of rich ore is developed and can be used with other deposits in the region. The classification is developed upon condition that two kinds of iron ore products are obtained:

- high-quality product with $\mathrm{Fe}_{\text {tot }}<67.0 \%$ and $\mathrm{SiO}_{2}>$ $>2.0 \%$, suitable for metallization (pellets, briquettes), powder metallurgy, etc.;

- high-quality agglomerates with $\mathrm{Fe}_{\mathrm{tot}}=53.0 \div 64.0 \%$ and $\mathrm{SiO}_{2}>10.0 \%$.

The generalized technological classification of principal rich ore types ion the Belgorod iron ore region of the Kursk Magnetic Anomaly defines a sound processing technology and application field for the given iron ore material (Table 4). The detailed study of iron ore type in each specific deposit may introduce amendments and updates, although, on the while, the classification totally serves the purpose.

Distinguished based on the obtained results on pretreatment of basic mineralogical varieties, the process types (grades) of ore include:

Grade I-iron mica-martite loose and half-loose ore for production of special purpose high-quality iron ore stock: deep concentration of such stock yields iron ore concentrates for powder metallurgy, accumulator and ferrite manufacture, etc.;

Grade II-martite-hematite ore: high-intensity magnetic treatment allows products for metallization, by-product is agglomerated ore, properly processed tailings-coloring pigments;

Grade III-iron mica-martite hard and half-hard oreproduction of agglomeration and blast-furnace ore;

Grade IV-hydrohematite-hydrogoethite varieties are recommended for the selective extraction and processing for production of coloring pigments and agglomerated ore.

\section{Conclusion}

1. Rich iron ore of the region is found to be a typical supergene product of ferrous quartzite residuum, the ore variety is governed by different mineral composition of parent rocks and by secondary carbonatization and chloritization processes.

2. The studies show considerable nonuniformity of physical and chemical properties, as well as grain size distribution and mineral composition of ore; great difference in the quality of hard and loose ore varieties is emphasized.

3. High mass fraction of iron as well as low mass fraction of slag-forming oxides makes it possible to consider the Belgorod iron ore as a source of high-quality stock for the coke-unfueled metallurgy and multi-purpose metallization products.

References

1. Orlov V. P., Verigin M. I., Golivkin N. I. Iron ore reserves of Russia. Moscow : Geoinformmark, 1998. 842 p.

2. Yushina T. I., Petrov I. M., Avdeev G. I., Valavin V. S. Analysis of state-of-the-art in iron ore mining and processing in Russian Federation. Gornyi Zhurnal. 2015. No. 1. pp. 41-47. DOI: $10.17580 /$ gzh. 2015.01 .08

3. Pomelnikov I. I. State and prospects of iron-ore industry development with stable decrease of global iron ore prices. Gornyi Zhurnal. 2015. No. 7. pp. 78-87. DOI: 10.17580/ gzh.2015.07.11

4. Rusinovich I. A., Nebosenko V. F. Gostichshevo iron ore deposit. Voronezh, 1964.81 p.

5. Dunai E. I., Belykh V. I., Pogoreltsev I. A. Industrial capacity of mineral and raw material resources in the Belgorod Region. Gornyi Zhurnal. 2014. No. 8. pp. 37-40.

6. Nikulin I. I. Connection of rich iron ore with metamorphogenic parent rocks in the Kursk Magnetic Anomaly. GIAB. 2015. No. 6. pp. 294-299.

7. Gzogyan T. N., Gzogyan S. R. Matenal constitution of rich iron ore in the Kursk Magnetic Anomaly. Nauchnye vedomosti BelGU. 2018. Vol. 42, No. 2. pp. 131-141.

8. Bulgakova A. P. Epigenetic conversion of rich iron ore in the Kursk Magnetic Anomaly. Synopsys Cand. Geol.-Mineral. Sci. Thesis. Voronezh, 1971. $19 \mathrm{p}$.

9. Nikulin I. I. Geology and genesis of supergenic Iron ore (in terms of the Kursk Magnetic Anomaly). Synopsys Doc. Geol. Mineral. Sci. Thesis. Moscow, 2017. 41 p.

10. Ergin Gülcan, Ozcan Y. Gülsoy. Performance evaluation of optical sorting in mineral processing-Acasestudy with quartz, magnesite, hematite, lignite, copper and gold ores. International Journal of Mineral Processing. 2017. Vol. 169. pp. 129-141

11. Wills B. A., Finch J. Wills' Mineral Processing Technology: An Introduction to the Practical Aspects of Ore Treatment and Mineral Recovery. 8th ed. Oxford: Butterworth-Heinemann, 2015. $512 \mathrm{p}$.

12. Papalambros P. Y., Wilde D. J. Principles of optimal design: modeling and computation. Third ed. Cambridge : Cambridge University Press, 2017. 376 p. 